\title{
The Importance of Entrepreneurship in Micro and Small Enterprises in Uncertainty and Barrier Scenarios
}

\author{
Marcelo T Okano ${ }^{1}$, Odir de Almeida Veiga ${ }^{1} \&$ Marcelo Eloy Fernandes ${ }^{2}$ \\ ${ }^{1}$ Post-graduation Unit, CEETEPS, São Paulo, Brazil \\ ${ }^{2}$ FATEC Baeueri, CEETEPS, Barueri, Brazil \\ Correspondence: Marcelo T Okano, Post-graduation Unit, CEETEPS, São Paulo, Brazil.
}

Received: April 20, 2021

doi:10.5430/ijba.v13n1p61
Accepted: May 20, 2021

Online Published: January 6, 2022

URL: https://doi.org/10.5430/ijba.v13n1p61

\begin{abstract}
Economic, political, and technological uncertainties require organizations to prepare adequately for new events that occur each day. Economic crisis, changes in the policies of each country and technological developments are classic examples of these changes in organizations. Seasonality is one of the economic phenomena that occur, and different forms of management are required. The seasonality that is described as a systematic and temporal imbalance of the tourist phenomenon that does not need to be regular, caused by the climate or by the vacation periods, and is based on the consumer behavior that can be expressed in terms of the number of visitors, traffic, highways, jobs, and tickets at attractions. Therefore, through a careful analysis of seasonality, it is possible that the losses are predicted, and the negative impact is not so grotesque on the company. For this, it is good that the manager uses the cost assessment methods to assume the seasonality of sales and thus be able to guard against the negative effects of the same. The objective of this research is to understand how owners of micro and small businesses in coastal cities consider themselves entrepreneurs or not and how they deal with obstacles such as seasonality through cost management. The methodology used was based on an exploratory and bibliographic research with a qualitative approach, seeking to analyze the triad: Entrepreneurship, Seasonality and Cost Management. The field research was applied through a semi-structured questionnaire to the sample of 100 Microentrepreneurs in the trade of goods and services in Caraguatatuba and São Sebastião, central cities of the North Coast of São Paulo. The main results show that most of the interviewed entrepreneurs perceive a certain impact caused by seasonality, understand the use of Cost Management to improve their processes and are adapted to one of the main costing methods highlighted by the bibliography.
\end{abstract}

Keywords: entrepreneurship, seasonality, coastal cities, cost management

\section{Introduction}

Economic, political, and technological uncertainties require organizations to prepare adequately for new events that occur each day. Economic crisis, changes in the policies of each country and technological developments are classic examples of these changes in organizations. The bigger the organization, the easier the re-adaptation of these new scenarios, but the problem is in the small and micro that does not have the same structure of the big ones and, they must fit.

Entrepreneurship is a way for micro and small companies to prepare to face the uncertainties and obstacles in the management and management of companies. A well-prepared entrepreneur can take care of your business and overcome the obstacles that appear, an example is the seasonality that occurs in the coastal cities and that companies are forced to focus the gains on the period from December to March, season that tourists are on vacation and spend with lodging, food, and fun in these cities.

Seasonality is one of the economic phenomena that occur, and different forms of management are required. Butler (2001) defines the seasonality that is described as a systematic and temporal imbalance of the tourist phenomenon that does not need to be regular, caused by the climate or by the vacation periods, and is based on the consumer behavior that can be expressed in terms of the number of visitors, traffic, highways, jobs, and tickets at attractions.

Seasonality can be recognized through a pattern, which occurs regularly in the same period each year (Butler, 2014). Therefore, certain seasons are considered high seasons, while others are considered low seasons. Seasonality requires 
managers to prepare for the high and low seasons, as in beach towns, the high season lasts four months.

Therefore, through a careful analysis of seasonality, it is possible that the losses are predicted, and the negative impact is not so grotesque on the company. For this, it is good that the manager uses the cost assessment methods to assume the seasonality of sales and thus be able to guard against the negative effects of the same.

The objective of this research is to understand how owners of micro and small businesses in coastal cities consider themselves entrepreneurs or not and how they deal with obstacles such as seasonality through cost management

\section{Literature Review}

\subsection{Entrepreneurship}

Entrepreneurship is a milestone on the road to economic progress and makes a tremendous contribution to the quality and future hopes of an industry, economy or even a country. Entrepreneurship is as important in small and medium-sized enterprises (SMEs) and local markets as in large companies, and national and international markets, and it is as fundamental a consideration for public enterprises as for private organizations. Entrepreneurship helps to stimulate competition in the current environment that leads to the effects of globalization (Soriano \& Huarng, 2013).

According to Leitão et al. (2011) entrepreneurship has been a strategic driver in facilitating the adjustment to technological change and supporting competitiveness in terms of place. In this context, the role played by entrepreneurship deserves further attention by scholars and public policy makers.

The potential role of entrepreneurs includes job creation, using privatized property for production, contributing to the development of a diversified economic structure, contributing to the economy's innovative capacity, and contributing to economic development through the generation of foreign sales and / or (Welter \& Smallbone, 2011).

Shane and Venkataraman (2000) define entrepreneurship as the "academic examination of how, by whom and with what effects, the opportunities to create future products and services are discovered, evaluated and exploited" Entrepreneurship activity in general terms, positively impacting growth because it is necessary to have a group of people willing to take the risk, using their resources to generate new businesses and businesses. This is the best way to achieve sustainable economic growth (NISSAN et al., 2011).

1- The definition considers the behavior of economic agents. For this reason, entrepreneurship does not mean an occupation, but an activity that considers the different circumstances and aspects of a person.

2- Entrepreneur must consider uncertainties and obstacles inherent in the process of setting up companies.

3- They should have information or ideas about efficient production processes as well as new organizational forms. This does not mean that entrepreneurs must have attended special academic courses on management. They should get the idea and can ask for information or expert advice to run the idea.

4- Entrepreneurs can also be found in large companies. In this case, they are called "intrapreneurs" or "corporate entrepreneurs" (Arendt and Brettel 2010).

The factor of entrepreneurship also includes people who seek information or ideas about efficient production processes as well as new organizational forms. Given these ideas, different types of ventures can be considered (Nissan et al., 2011).

According to Hisrich \& Peters (2002), entrepreneurship is characterized by an ability to identify opportunities and create something innovative under conditions of uncertainty, assuming the risks involved. Persistence and vision of the future involve the process of undertaking that results in a new way of doing work - a new product, service, or activity - or the creation of a new enterprise.

Dana and Dana (2005) consider the entrepreneur as the one who assumes the risk of being autonomous, a taker of non-quantifiable risks and profits as a reward that owner-managers receive for taking risks and an individual experiencing a new combination (Cantillon, 1756, Knight, 1921, Schumpeter, 1931).

\subsection{Types of Entrepreneurs}

As there is no single type of entrepreneur, it is not possible to enclose it in a standard model (Zampier, Takahashi, 2011). However, Table 1 presents the types of entrepreneurs defined by Vesper (1980), Miner (1996), Filion (1999) and Dornelas (2015). 
Table 1. Types of entrepreneurs

\begin{tabular}{|c|c|c|}
\hline & $\begin{array}{l}\text { Type of } \\
\text { Entrepreneur }\end{array}$ & Behavioural Characteristics \\
\hline \multirow[t]{12}{*}{ Vesper (1980) } & Self Employed & They perform their services in person, relying on technical skill. \\
\hline & Team Leader & $\begin{array}{l}\text { They hire other people and delegate tasks, forming teams, realizing a } \\
\text { possible advantage in the expansion of the business. }\end{array}$ \\
\hline & $\begin{array}{l}\text { Independent } \\
\text { innovator }\end{array}$ & $\begin{array}{l}\text { Creators of new products, which would create companies to develop } \\
\text { them. }\end{array}$ \\
\hline & Pattern Multiplier & They recognize a business that can be multiplied for profit. \\
\hline & $\begin{array}{l}\text { Scale Economy } \\
\text { Explorer }\end{array}$ & $\begin{array}{l}\text { They create their businesses based on lower prices obtained due to } \\
\text { economy of scale, location in cheaper areas and / or with lower taxes. }\end{array}$ \\
\hline & $\begin{array}{l}\text { Capital } \\
\text { Aggregator }\end{array}$ & $\begin{array}{l}\text { They raise funds from various sources to finance the operation of } \\
\text { banks, }\end{array}$ \\
\hline & Acquisition & $\begin{array}{l}\text { They choose to acquire businesses that are already in the process of } \\
\text { operating. }\end{array}$ \\
\hline & $\begin{array}{l}\text { Specialist in } \\
\text { Buying } \quad \text { and } \\
\text { Selling }\end{array}$ & $\begin{array}{l}\text { They buy companies in distress, get them back and then sell them at } \\
\text { a higher price. }\end{array}$ \\
\hline & Cluster Trainer & $\begin{array}{l}\text { They work to obtain shareholding control of a company to acquire } \\
\text { control of other companies. }\end{array}$ \\
\hline & Speculator & $\begin{array}{l}\text { They dedicate themselves to buying and selling commodities, such as } \\
\text { real estate. }\end{array}$ \\
\hline & $\begin{array}{l}\text { Apparent Value } \\
\text { Manipulator }\end{array}$ & $\begin{array}{l}\text { They buy cheap goods or companies, improving their appearance or } \\
\text { financial indexes to resell them with a price increase. }\end{array}$ \\
\hline & $\begin{array}{l}\text { Personal } \\
\text { Entrepreneur }\end{array}$ & $\begin{array}{l}\text { He seeks to be good at everything he does, has initiative and } \\
\text { commitment to the organization, seeks to work based on personal } \\
\text { goals planning. }\end{array}$ \\
\hline
\end{tabular}

Miner (1996)

\begin{tabular}{ll}
\hline $\begin{array}{l}\text { Idea Generator } \\
\text { Specialist }\end{array}$ & $\begin{array}{l}\text { It seeks innovation, seeks to achieve company strategies through new } \\
\text { products, new niches, and new processes. Has a good degree of } \\
\text { intelligence, desire for ideas and try not to take risk? }\end{array}$ \\
\hline $\begin{array}{l}\text { Empathy, } \\
\text { Supervisor }\end{array}$ & $\begin{array}{l}\text { Believes that the right path to business success is the strength of } \\
\text { sales, considers social processes, good relationships with individuals, } \\
\text { seeks to understand them }\end{array}$ \\
\hline True Manager & $\begin{array}{l}\text { He is the one who tries to adapt to manage a position of high } \\
\text { leadership, has the desire to be able, relates in a satisfactory way with } \\
\text { the authorities, seeks the business competition, besides having a } \\
\text { good decision-making capacity. }\end{array}$ \\
\hline Lumberjack & $\begin{array}{l}\text { It is characterized by the enjoyment of doing things, it feels like you } \\
\text { are wasting time when you must talk to people, while the employer } \\
\text { prefers people who work for many hours like himself, and the } \\
\text { organizational culture of your enterprise is geared for production. }\end{array}$
\end{tabular}

Filion (1999)

Seductive He delivers completely and emotionally to business, but his enthusiasm never lasts long. He creates business and soon sells it, likes things to happen quickly. Seeks where and how to make profits 
with the least possible effort.

\begin{tabular}{ll}
\hline Player & $\begin{array}{l}\text { He perceives sport and leisure as a vital element in his life. It } \\
\text { considers the company a financial support, a means of earning } \\
\text { enough to do what it really wants. opt for seasonal fields of action. } \\
\text { You are not emotionally committed to the business. }\end{array}$ \\
\hline Hobbyist & $\begin{array}{l}\text { Dedicate all your energy and free time to business. He often has } \\
\text { another official job, but only maintains it as financial support for his } \\
\text { business. Business is his hobby. It is in him that sees the possibility } \\
\text { of self- realization, thus invests all the resources to develop it. }\end{array}$ \\
\hline Converted & $\begin{array}{l}\text { Looking for something to achieve, when you find what you are } \\
\text { looking for, your life revolves around this discovery. He prefers to } \\
\text { ree himself as a particularly superior person, instead of seeing the } \\
\text { until the other person proves to be trustworthy. }\end{array}$
\end{tabular}

Missionary You know the product and the market very well. It considers the evolution and learning of individuals, understands the business as a social system, believes that the results depend on teamwork. Delegate as much as possible, participate in task force activities, where they can listen to discuss and exchange experiences.

\begin{tabular}{|c|c|c|}
\hline \multirow[t]{8}{*}{ Dornelas (2015) } & $\begin{array}{l}\text { Native } \\
\text { (Mythological) }\end{array}$ & $\begin{array}{l}\text { They are usually the best known and acclaimed. Their stories are } \\
\text { brilliant and often start out of nowhere and create great empires. }\end{array}$ \\
\hline & $\begin{array}{l}\text { Learn } \\
\text { (Unexpected) }\end{array}$ & $\begin{array}{l}\text { This type of entrepreneur has been very common. He is usually a } \\
\text { person who, when he least expected, was faced with a business } \\
\text { opportunity and made the decision to change what he did in life to } \\
\text { dedicate to the business itself. }\end{array}$ \\
\hline & $\begin{array}{l}\text { Serial (Create } \\
\text { New Business) }\end{array}$ & $\begin{array}{l}\text { The serial entrepreneur is the one passionate not only for the } \\
\text { companies he creates, but mainly for the act of undertaking. It is a } \\
\text { person who is not content to create a business and stay ahead of it } \\
\text { until it becomes a big corporation. }\end{array}$ \\
\hline & Corporate & $\begin{array}{l}\text { The corporate entrepreneur has become more prominent in recent } \\
\text { years, owing to the need for large organizations to renew, innovate } \\
\text { and create new business. }\end{array}$ \\
\hline & Social & $\begin{array}{l}\text { The social entrepreneur's mission is to build a better world for } \\
\text { people. }\end{array}$ \\
\hline & by necessity & $\begin{array}{l}\text { The entrepreneur by necessity creates his own business because he } \\
\text { has no alternative. }\end{array}$ \\
\hline & $\begin{array}{l}\text { Heir (Family } \\
\text { Succession) }\end{array}$ & $\begin{array}{l}\text { The heir entrepreneur soon receives the mission of taking the legacy } \\
\text { of his family ahead. }\end{array}$ \\
\hline & $\begin{array}{l}\text { "Normal" } \\
\text { (Planned) }\end{array}$ & $\begin{array}{l}\text { Every theory about successful entrepreneurs always presents } \\
\text { planning as one of the most important activities developed by } \\
\text { entrepreneurs. }\end{array}$ \\
\hline
\end{tabular}

In this research we adopted the definitions of types of entrepreneurs of Dornelas (2015).

\subsection{Entrepreneurial Companies}

According to Kuratko (2011), entrepreneurial companies make two indispensable contributions to market economies. First, they are an integral part of the renewal process that permeates and defines market economies. Entrepreneurs play a crucial role in the innovations that lead to technological change and productivity growth. In short, it is about change and competition because they change the structure of the market. Market economies are dynamic organic entities always in the process of "becoming", rather than an already established entity that has already arrived. They 
are about prospects for the future, not about the heritage of the past.

Second, enterprising companies are the essential mechanism by which millions enter the conventional economy. Entrepreneurship enables millions of people, including women, minorities, and immigrants, to have access to the pursuit of economic success. The biggest source of the US force, for example, has always been America's dream of economic growth, equal opportunity, and upward mobility. In this evolutionary process, entrepreneurship plays the crucial and indispensable role of providing the "social glue" that links high-tech and "mainstream" activities (Kuratko, 2009, 2011).

According to Audretsch (2017) a company or organization is considered an entrepreneur based on its performance. Performance is usually measured in terms of a desired outcome, such as innovation or growth.

\subsection{Seasonality}

Seasonality, in its contextual sense, can be defined as a certain period for the occurrence of a phenomenon, that is, according to what occurs in some periods and in others not (Scheuer \& Miguel, 2011).

Scheuer \& Miguel (2011) considered that seasonality is the concentration of tourist flows in short periods of the year, promoting, on the one hand, peaks in general service activities and tourists, who often constitute a heavy burden for the physical and social resources in the destination area and, on the other hand, times of low demand that generate inefficiency in the tourist activity of a place or region.

Seasonality, according to Almeida and Kastenholz (2008), is generally recognized in the literature as a phenomenon of predominantly economic character since it is consensually related to the adversity of its consequences in this plan, both for the destination areas and for the companies.

Seasonality is defined by a behavior that always happens at the same time within a specific interval, that is, a standard behavior that is repeated from time to time, or as a phenomenon resulting from the fluctuation of demand in certain periods (MOTA, 2001 ; PORTO et al, 2017), similarly, the Brazilian Entrepreneur Support Service SEBRAE indicates that seasonality is identified through the fluctuation, positive or negative, of the demand for a product or service at a certain time of the year. Likewise, the beer and ice cream trade increases in times of high temperatures, such as summer, as it is the time when people are looking for something to cool off, just as the chocolate industry sells more at Easter time, due to the social custom of consuming Easter eggs.

Seasonality can occur in different periods and variables, and by different patterns (REMBEZA et al., 2016), this phenomenon does not depend on a fashion, it acts as a characteristic period where sales increase due to some specific event, and that this event has a repetition, it is also emphasized that seasonality affects the most diverse economic activities and can cause uncertainty and influence the profitability of companies (MESQUITA et al., 2016).

\subsection{Seasonality in Tourism}

According to Almeida and Kastenholz (2008), tourist seasonality reaches global levels, but it is more prevalent in countries that distance themselves from the Equator, in these areas, seasonality has been a concern of public policies and the private sector to reduce its negative effects. In addition to geographic location, there are still other factors that may condition Tourist Seasonality, (ROCHA et al, 2017; DENCKER, 1998) such as: demographic, sociological and economic, it is necessary to consider vacation periods, whether they are school days or work and the purchasing power of the population (MOTA, 2001). Barros (1998) classifies the natural factors, which are motivated by the influences of the seasons that include periods of rain or drought, and, cultural factors, which are motivated by the socioeconomic and cultural calendar that includes holidays, additional payments, dates religious holidays and long holidays. Therefore, in general, we can list several factors such as: demographic, sociological, economic, cultural, and natural factors as factors in the Tourist Seasonality.

Degen (1989) as well as the Brazilian Entrepreneur Support Service - SEBRAE (2016) offers due emphasis to seasonality as the first in a list of several risk factors, and also complements that this factor has a higher frequency in summer-related businesses, such as: ice cream, ice, draft beer, swimsuit and others similar, (SAMPAIO, 2006) emphasizes that in coastal regions the desire to be on the beaches is for relaxation, strolling through the sand, swimming in the sea or practicing sports, and, especially during the summer, results in tourist seasonality, which alternates between seasons of high visitation and idleness.

In some locations, tourist seasonality is the main responsible for the development of economic activity, generating numerous opportunities for entrepreneurship in general in periods of high visits (SUPRIATNA et al., 2017); On the other hand, negative consequences occur in periods of low visitation, according to Mota (2001, p.98), some unpleasant occurrences are unemployment, mortality mainly in micro-companies, drop in the turnover of tourist 
companies, changes in the management system, compromise of the quality of service, price changes, among others.

The opportunities to develop tourist activities in the high visiting seasons require the dedication of entrepreneurs, which may be scarce in certain regions, so in some cases entrepreneurial migration is seen as a potential strategy to stimulate new economic development (CARSON, CARSON, EIMERMANN; 2017).

\subsection{Impact on Business}

There are many types of existing risks, and all can negatively affect the survival of the entrepreneur's business, however seasonality is classified as an economic risk that is directly linked to the company's survival (CHIAVENATO; 2008); The Brazilian Entrepreneur Support Service - SEBRAE (2016) and Degen (1989 p.40) also highlight seasonality as the first among other aspects of business risk, possibly due to the varied consequences that this phenomenon can produce, such as: unemployment, mortality in micro-enterprises, decreased revenue, changes in the management system and also in the quality of care (MOTA, 2001, p. 98).

However, the highlighting of seasonality as a risk is understood in a direct correlation of risk to the enterprise by the possibility of triggering disastrous consequences not only for the entrepreneur through the loss and the possible triggering of bankruptcy, but the threat is also observed for employee's unemployment, for customers due to the inconveniences that can be caused by the failure to meet their demands and even for the supplier not to receive for their products or services.

Therefore, through a careful analysis of seasonality, it is possible that the losses are predicted, and the negative impact is not so grotesque on the company. For this, it is good that the manager uses the cost assessment methods to assume the seasonality of sales and thus be able to guard against the negative effects of the same.

\subsection{Costs Management}

There are several tools that have a certain relevance for entrepreneurship, information on costs can support decision making, and their analysis in the decision-making process can lead to the improvement of the results of organizations (PICCOLI; GASPARETTO, 2015), their contributions in the management of information not only occur in complex environments like the industrial one, but in all the others.

Bruni (2010) points out that the first studies on costs started after the Industrial Revolution to provide information that helps not only decision making, but also the control of operations; Martins (2003) explains that, in view of the growth in competitiveness, the use of cost analysis for decision making has become extremely essential not only in the industrial sector, but also in the commercial and services sectors.

Cost management makes it possible to know the total value of the products and better elaborate the sales price, measure billing, profit, or loss more accurately, and eliminate unnecessary loss of resources, ensuring greater security in negotiations. (LOBRIGATTI, 2003; BRUNSTEIN, 2005; ALMEIDA, 2017).

The development of the economy exercised by entrepreneurship requires cost analysis (RAJ, 2016), its understanding as a fundamental competence is linked to the establishment, management, and growth of companies (KIMUNDUU; ERICK; SHISIA, 2016), in general, observed it is known that the application of planning, control and decision functions that are possible through cost analysis are fundamental for business success (SALAKO; YUSUF, 2016)

\section{Methodology}

This research can be classified as exploratory and qualitative. For Gil (2002), exploratory research aims to provide greater familiarity with the problem, to make it more explicit. Zikmund (2002) considers that exploratory studies are carried out to clarify ambiguous problems, and research is needed to better understand the dimensions of the problems.

The option for qualitative research follows the definition of Dana \& Dana (2005), in which the advantages of qualitative research (as opposed to quantitative) include the ability to learn directly from the research subject, thus reducing common measurement errors in surveys of studies that often need to make assumptions and the result is a deeper holistic understanding.

The qualitative approach presents a reality that cannot be quantified or measured and involves subjective items from the reality of the research. It is possible to work with the data without specific statistical treatment, seeking to understand the reality (Costa, 2001). This research has the following characteristics:

- Population and Sample

The population of this research is composed of Microentrepreneurs in the trade of goods and services, located in the 
central cities of the North Coast of São Paulo: Caraguatatuba and São Sebastião. The economy of this region is based on the oil industry, port activity and, mainly on tourism.

The sample of 100 Microentrepreneurs within a population of 31,664 active companies (JUCESP; 2018), also considering the existence of informal ones that it was not possible to quantify, can be classified as non-probabilistic chosen for convenience because it constitutes a group of individuals with greater accessibility to the researcher and being more appropriate considering time, cost and practicality, because of this, although the sample is not representative it was possible to increase efficiency.

\section{- Data collection instrument}

The instrument of this work was composed by a script of semi-structured interviews, with open questions. Some of the answers were directed by the interviewer, in the form of performance notes that aim to detect the degree of importance, according to the intensity of perception for that question.

The type of interview applied was semi-structured, this format was chosen because of the breadth of its application with various segments of the population, regardless of the level of education or area of expertise of the interviewees, given the greater flexibility that consists in repeating the question or until formulating it in a more accessible way to the interviewee if necessary, thus ensuring greater understanding of the questions and consequently that the information answered is more accurate and reliable, this method also makes it possible to obtain data that are not specifically found in documentary sources (Gil ; 2007).

Considering the objectives of this research and the specialized literature that was used in the theoretical framework, a script was initially prepared with fifteen questions to explore in the interviews; To verify both the fulfillment of the research objectives and the understanding of the questions by the interviewees, a pre-test was carried out with 20 interviewees between December / 2016 and January / 2017. The script is in the annex

- $\quad$ Field research

The interviews effectively took place after a presentation based on the preliminary stages in the schedule:

- Researcher's identification upon presentation of the student identification card and civil identification document.

- Explanation about the Research, Institution and Advisor.

- Presentation of the Informed Consent Form.

Only after agreeing to participate in the research, does the interview based on the script begin, where the filling in was conducted by the researcher with the help of the interviewed entrepreneur, who conducted the filling expressing his opinions.

The interview in the entrepreneur's own work environment was often divided between the service of one and the other client, this approach brought a greater understanding of the research problem.

During the interview, it was possible to delve into the most important subjects that stimulated understanding until obtaining as much information as possible that allowed the study to be carried out.

At the end of each interview, the following steps were taken for the outcome:

- Photographic record of the researcher and interviewee at the interview site.

- Thanks for the collaboration with the research.

- Communication of the researcher's email and telephone to resolve any doubts.

- Analysis of results

After conducting the field research by filling out the interview scripts, the data were gathered in an online remote storage electronic spreadsheet, specifically designed for this purpose, and, subsequently, the analysis was performed using graphs, which enabled the researcher to interpret the results of the research.

\section{Results and Analysis}

\subsection{Characteristics of Respondents}

Figure 1 shows the distribution of companies according to size: informal - Companies that do not pay any kind of tax, MEI - Individual Microentrepreneur has annual revenues of up to R \$ 81 thousand and Microenterprise has annual revenues of up to R \$ 360 thousand. Most of the companies surveyed are Microenterprises, then the MEIs and, lastly, the informal ones. These data demonstrate that entrepreneurs are concerned about having a legalized organization $(93 \%)$ and paying taxes and obligations governed by the law. 


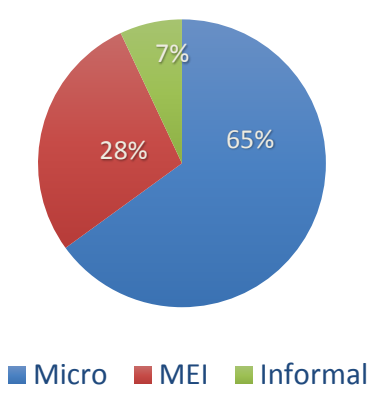

Figure 1. Distribution of the type of company

Source: Research Data

As for the size of the companies, it was found that Microenterprises with $65 \%$ of the sample prevailed, right after Individual Microentrepreneurs (28\%) and a peculiar characteristic, informality, which corresponds to $7 \%$ of the sample.

Among the informal Entrepreneurs, a certain fear of participating in the research stood out, due to the visible concern that the interviews were the work of inspection of irregular trade that is carried out by the Municipal Governments where goods seizures commonly occur, something very common in this region during the months of high seasonality.

In addition to informality, and the predominance of smaller entrepreneurs who prevailed absolutely in the sample, where $100 \%$ of the interviewees are classified up to Microenterprise, it was possible to verify the greater frequency of products related to summer, mainly regarding drinks and ice cream as described by Degen (1989), and there were also tourists among customers of the group of products listed as snacks and meals, a fact very common in coastal regions (SAMPAIO, 2006).

Figure 2 shows how the products and services marketed by the companies are distributed, it is noticed that most of the establishments (first and third place) are related to food and the second to the civil construction. According to Scheuer \& Miguel (2011), the coastal area receives tourists who prefer to eat their meals outside the home, as seasonality is the concentration of tourist flows in short periods of time. year, promoting, on the one hand, spikes in general service activities and tourists. The area of civil construction is also justified due to the large number of buildings and renovations of houses and summer apartments outside of the seasonality.

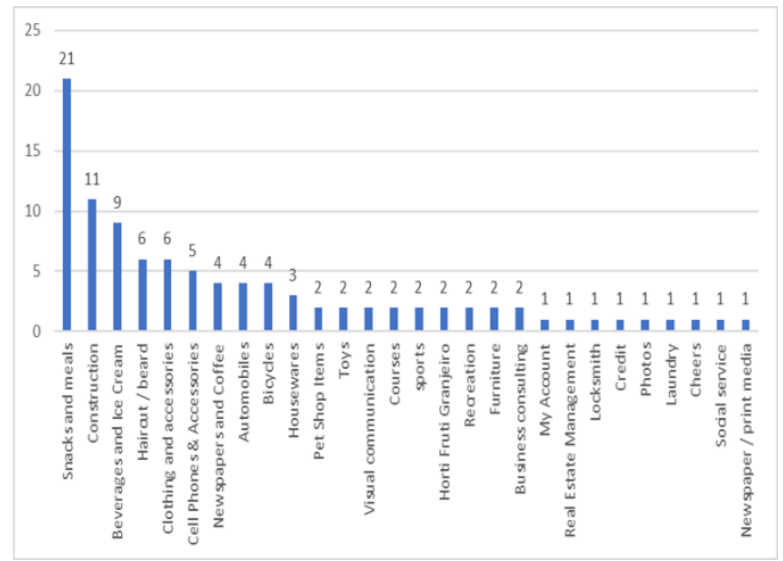

Figure 2. Distribution of products and services

Source: Research Data

The three groups of main products that obtained the most frequency in the sampling is respectively: Snacks / Meals 
(21\%), Civil Construction (11\%) and Beverages / Ice Cream (9\%), together these three groups represent $41 \%$ of the present sample.

The first group, called Snacks / Meals, comprises the following establishments: bars, snack bars, restaurants, and pizzerias; the Civil Construction group covers both construction material deposits and service providers; and a group called Drinks / Ice Cream includes: coconut water stalls, sugarcane juice, ice cream parlors, ice cream.

A relevant aspect verified was the intense demand for Drinks and Ice Cream, evidenced in most of the interviews, where it was necessary to take brief breaks every approximately five minutes for the interviewee to perform the service of his clients, both in the interviews with the Entrepreneurs who worked in individually and with those who had employees in their company, so it was possible to check the intense demand for the products of this group on a frequent basis.

The next three groups of main products with less representation, which together represent $17 \%$ are related to the items: Hair / beard cut, Clothing / accessories and Cell phones / accessories.

Other groups with less representativeness, which, although they account for $42 \%$ of the sample, each individually does not exceed 4\%, are related to the items- Newspapers / coffee, Car items, Bicycles, Housewares, Pet shop items, Toys, Visual communication, Courses, Sports, Horti fruti granjeiro, Leisure, Furniture, Business consultancy, Musical articles, Real estate advice, Locksmith, Credit, Photographs, Laundry, Health, Social work, and Newspaper / print media

In general, in these groups of main products with less representativeness in the sample, it was observed in the interview moments that although these companies present a more balanced demand, the participation of the Entrepreneur in the business work routine and the service to clients of like the one highlighted in the previous item.

\subsection{Seasonality}

To verify if the seasonality affects the business, it was questioned about the monthly invoicing during the year, where in each month of normal billing was considered as 1 and in the months of the seasonality (November to February) the increase was considered as the amount proportional to the billing normal. To verify if the interviewees prepare for seasonality, the number of employees was questioned month by month during the year.

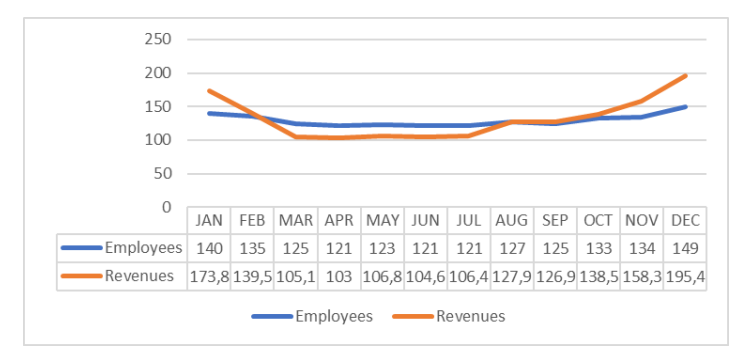

Figure 3. Revenues and number of employees

Source: Research Data

Figure 3 shows the evolution of revenues and employees during the year. It can be observed that during the months of seasonality (November to February), the revenues increased considerably, being the average of the months out of the seasonality, 114.8 and 166.7 in the months of seasonality, an increase of $145 \%$. The number of employees also increases in seasonality, the average number of employees out of seasonality is 125 staff and seasonally, the monthly average of employees rises to 137 , an increase of $110 \%$.

The data confirm that respondents are concerned with seasonality and are prepared to meet the peak of public generated and is generally recognized in the literature as a phenomenon of predominantly economic character since it is consensually related to the adversity of its consequences in this plan, both for the destination areas and for the companies that operate them (Almeida and Kastenholz, 2008).

However, in general, it was found that the majority of the sample, mainly the entrepreneurs who work with food and drinks, perceive in December its season of high seasonality, this variation of the billings oscillates between $50 \%$ and $250 \%$, but in some it reaches up to $1,900 \%$, and, even among most of the others that do not have their main sales 
period in December, they understand that they work previously to meet the aforementioned high demand in December, in this period, the majority also informed that despite not needing to make temporary hires distributes employees' vacations only in the months when there is no high seasonality, among those who need to make temporary hires it has been reported that this increase in employees varies between $20 \%$ to $200 \%$.

The high variations in revenue and employees that occurred mainly in the month of December show the impact that seasonality generates on the economic development of this region, both positively in the periods of high, and negatively during the low visitation, as explained by Supriatna et al. (2017) and Mota (2001).

\subsection{Entrepreneurs}

It is possible to observe, in Figure 4, that the selected sample covered all types of entrepreneurs addressed in the theoretical framework, however, each type analyzed presented unique particularities that are explored individually in the next paragraph in decreasing order, that is, from the largest to the smallest representative portion of the sample.

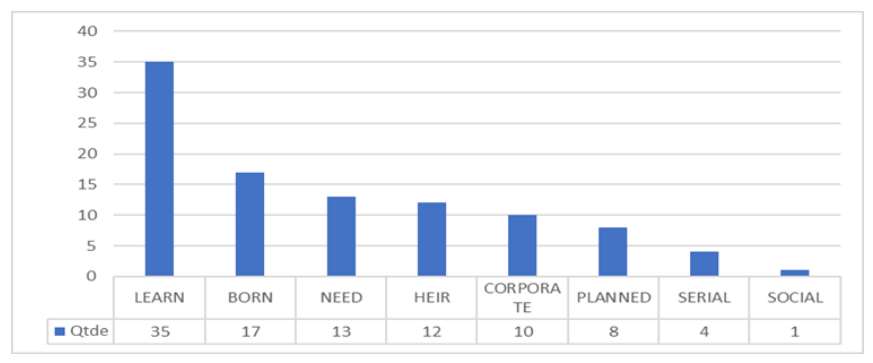

Figure 4. Profile of the entrepreneurs, according to Dornelas (2015)

Source: Research Data.

The most frequent type of entrepreneur in the present sample, formed by $35 \%$ of the interviewees, is the "who learns" type, the main characteristics evidenced were the unpredictability of the opportunity to undertake, the perception and learning of the business. Thus, we highlight the case of an entrepreneur who, after returning to Brazil, used his experience acquired while working in a large multinational company in Japan to initiate his entrepreneurial activity by opening a juice shop, the unpredictability of the opportunity came from one of its products, açaí, and, after realizing the possibility of existing business in this specific product, it was necessary to follow a constant learning journey to specialize in this product and currently be recognized as outstanding talent, among those who practice this activity in the region, the former juice shop opened an opportunity to work in the açaí branch and today serve at three addresses located in the main commercial points of the region under analysis.

The second most constant type of entrepreneur, $17 \%$ of the sample is the "born" entrepreneur, this type has the following characteristics: premature beginning of professional life, idealism and commitment, one of the interviewees highlighted that the experience acquired when he was still a teenager and learned working in his family's ventures helped him when he invested in his own business and took on the area that he would like to work in for a long time, this business in which he works today, a beauty salon, has been an ideal goal since he was a child, who at the same time over time it has committed itself to learn more about this area and currently consolidate itself as a reference in its segment in the region.

The third type of entrepreneur most frequently, totaling $13 \%$, is the entrepreneur due to "need", highlighted as the one who inevitably had to undertake because he needed this personal fulfillment or most of the time, due to lack of work, that is, the one who he was unemployed. Among the entrepreneurs who classified themselves as this type, there is a report that, despite the start of the stamping venture, which was managed by his parents when he was still a child and helped part of the services, the real learning and growth in this area came after his death. from his father when the family ended their activities and needed to sell the commercial property for financial reasons, but he was still a teenager, still performing part of the graphic services he learned in printing at home. Despite the knowledge in practice, he sought training and specialization in this area, and, currently after more than 10 years after the death of his father, the closure of family activities and the sale of the commercial property, this entrepreneur rented this same property for restart the commercial activity that was previously carried out by their parents, highlighting both the need for work and the need for personal fulfillment. 
However, this part of the research, where entrepreneurs were segmented into types to classify them in the sample, could highlight the main characteristics presented in the theoretical framework and compare them with the perception of each entrepreneur in the field, but, fundamentally, it was possible to identify, in a broad way, that all interviewees have characteristics of entrepreneurs as the bibliography describes them, regardless of the specific type, this finding attests based on the theoretical framework that the sample is formed by entrepreneurs.

\subsection{Costs Management}

It was asked about the main resource used to perform the calculation of costs and profit as shown in Figure 5:

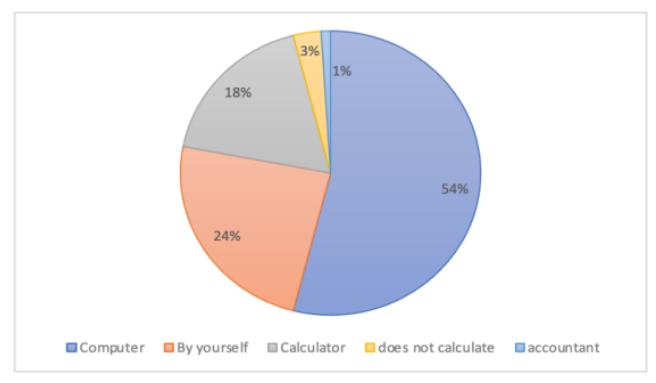

Figure 5. Main resource used to calculate costs

Source: Research Data

The results showed that the most used resource among the interviewees is the "computer", $54 \%$ of the entrepreneurs affirm that they use this resource to carry out the main calculations to calculate, control, and manage the costs of their business, among this majority being highlights the use of electronic spreadsheets with simple formulas customized for the specific situation of your company, some use more sophisticated business management systems, others still use spreadsheets similar to those described above through remote access.

A smaller portion, 24\%, reports that they perform the necessary calculations to manage costs through "head calculation" as this technique is more popularly known, that is, making the count mentally, without using registration or confirmation of the final values obtained.

The use of a "calculator" in the aid to manage costs was declared by $18 \%$ of the interviewees, it was possible to verify that this portion of the sample, despite not using sophisticated techniques, normally performs the calculations and records of approximately all costs involved in the routine of your business activity.

A smaller portion (3\%) reports that they "do not calculate" the costs involved in their activity, in this respect some of these interviewees report only that the amount left over at the end of the working day is considered profit.

An even smaller portion (1\%) described that they leave to their "accountant" the calculations they need to carry out cost management, despite this highlighted the importance of carrying out cost management in order to create a containment reserve to subsidize fixed costs during the period of low sales, and that this accounting support is only possible because the accountant is a partner in the company, since most accounting services provide only tax support.

The next aspect verified in the interviews was whether the decisions are made based on cost calculations, that is, if the entrepreneurs consider the information about costs useful to manage their company, Figure 6 presents the results obtained:

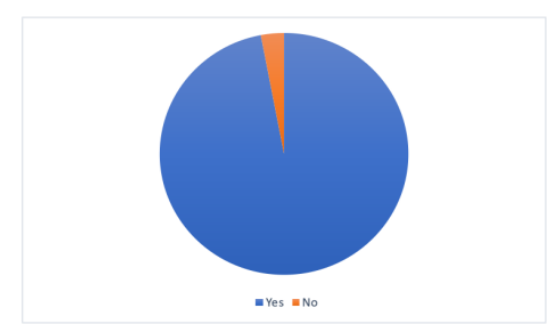

Figure 6. Decision making based on cost calculation 


\section{Source: Research Data}

Regarding the use of cost management for decision making, it was found that $97 \%$ of the interviewed entrepreneurs declared that they decide based on the cost calculations to manage their enterprise, whether through a computer, calculator, head or even with the help of accounting professional.

It was also found that among the 3\% contrary to this practice, reasons related to the level of education stood out, or even for believing that it is not necessary because of the experience he has in the business.

The next element aims to verify if the interviewed entrepreneur uses the information generated by the accounting service provider to manage his business, there is thus adaptability to absorption costing, which is the only method accepted by Brazilian tax legislation, as addressed in the theoretical framework, commonly the focus of the accounting professional is to meet tax requirements, this information is presented in Figure 7:

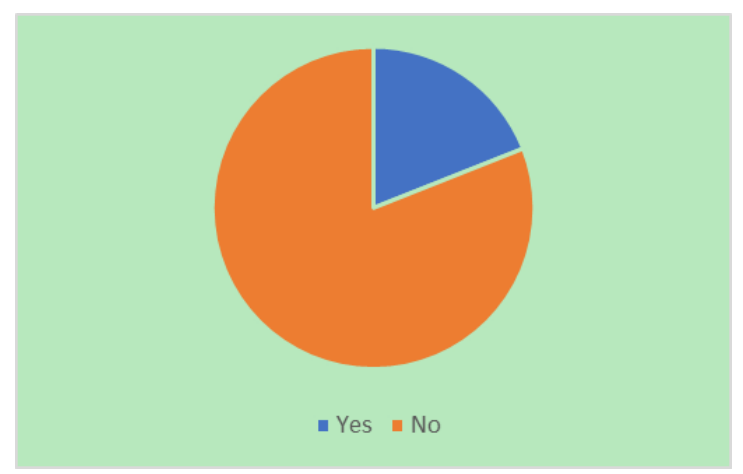

Figure 7. Use of information generated by accounting for management

Source: Research Data

It was found that most of the interviewed entrepreneurs, comprised in $81 \%$ of the sample, do not use the information generated by the accounting professional for the management of their respective companies, thus, through a preliminary analysis, it was possible to verify that the adaptability to this costing method is low among the analyzed sample.

In addition, it was possible to detect that there is a concern among entrepreneurs not only about carrying out the calculations, but also its practical applicability, since most of the interviewed entrepreneurs reported making decisions based on the cost calculations to manage their enterprise.

\section{Conclusions}

The objective of this research was to understand how the owners of micro and small companies in coastal cities consider themselves entrepreneurs or not, it can be proven through the research that the interviewees consider themselves entrepreneurs, are willing to learn and seek the best way to lead companies. In situations of uncertainty, such as seasonality, respondents adjust to new scenarios such as an increase in the number of employees and provisioning of resources in the low-billing months.

It was found that most respondents are entrepreneurs, and each has a characteristic profile, it was noted that entrepreneurship is formed by several characteristics mainly related to innovation to create the new, organization to manage, high level of risk tolerance, minimizing costs due to the scarcity of resources generated by seasonality, meeting demand in each consumer market, and identifying opportunities for transformation into business.

Two main criteria were used to check the degree of seasonal variation, they are: the billing fluctuation and the fluctuation of employees. The first criterion used, called billing, showed that $89 \%$ of the interviewed entrepreneurs declared that their activities have fluctuations in billing in specific periods, they are: during the month of December, just before the month of December, except in December and January, in specific days of the week, later disclosure periods, immediately after fluctuations in the quality of the services offered by its main competitor and between the months of February and June on account of holidays. The oscillations result in an increase in revenue of up to $250 \%$ in the majority, and in some cases can reach up to $1900 \%$. 
The second criterion, which sought to show fluctuations in the workforce, where it was found that despite the great majority of entrepreneurs report that there are no fluctuations during the year, they schedule the employees' vacations during the low season months, so that all its workers is present during the period of high seasonality, it was also found that a small portion reported that it was necessary to increase its staff by up to $200 \%$.

Seasonality is perceived in most of the sample, especially among entrepreneurs who work with food and drinks, its greatest impact is perceived by the positive fluctuations in sales that vary between $50 \%$ and $1900 \%$, in most cases during the month of December, but some declare this occurrence in different periods such as municipal holidays, seasonality was also evidenced the need for temporary hiring of employees, which can vary between $20 \%$ and $200 \%$ in the aforementioned periods, thus, it was possible to identify the relationship of innovative attitudes in entrepreneurship in order to meet the specific demands of the region under analysis, in all cases there is some kind of fluctuation in demand, a condition is present that can contribute to reducing the survival of these companies. The main aspect perceived about Cost Management was its use as a support for decision making by most entrepreneurs, only a small portion believes it is not necessarily due to the experience they have in the business.

It was possible to provide questions related to the theme: Entrepreneurship, Seasonality and Cost Management, for projects to be studied later, therefore, the main points to be researched are listed from the next paragraph:

- Expand the collection to obtain a more comprehensive sample in a certain segment of the population of Microentrepreneurs located in other regions, highlighting their seasonal particularities through a comparative analysis.

- Implement management through variable costing through action research, to establish a relationship between theory and practice, to analyze, in a deeper way, the exclusive benefits of this costing method in the business context.

- Determine the variations between survival and mortality that occurred in the companies sampled throughout the research, and their relationship with variable costing through a longitudinal design.

\section{References}

Almeida, A. D., \& Kastenholz, E. (2008). A sazonalidade no turismo e an estratégia de diversificação da procura: O Caso do Norte de Portugal. Proceedings do $2^{\circ}$ Encontro Luso-Brasileiro de Estratégia e Slade Brasil, 20-22.

Arendt, S., \& Brettel, M. (2010). Understanding the influence of corporate social responsibility on corporate identity, image, and firm performance. Management Decision, 48(10), 1469-1492. https://doi.org/10.1108/00251741011090289

Audretsch, D. B. (2017). Entrepreneurship and universities. International Journal of Entrepreneurship and Small Business, 31(1), 4-11. https://doi.org/10.1504/IJESB.2017.083802

Barros, M. D., et al.. (2017). Análise Multicritério Em Dados Sobre Empreendedorismo: Um Estudo Bibliométrico. Revista Produção Online, Florianópolis, 17(3), 1069-1089. https://doi.org/10.14488/1676-1901.v17i3.2764

Butler, R. (2001). Seasonality in tourism: Issues and Implications. In T. Baum, \& S. Luntopr (Eds.), Seasonality in tourism. Oxford: Pergamom. https://doi.org/10.1016/B978-0-08-043674-6.50005-2

Butler, R. (2014). Addressing Seasonality in Tourism: The Development of a Prototype. Madrid: UNWTO: World Tourism Organization.

Cantillon, R. (1756). Essai sur la nature du commerce en general. Gyles, R., London and Paris.

Carson, D. A. (2017). International winter tourism entrepreneurs in Northern Sweden: Understanding migration, lifestyle, and business motivations. Scandinavian Journal of Hospitality and Tourism. Northern Institute. https://doi.org/10.1080/15022250.2017.1339503

Chiavenato, I. (2008). Treinamento E Desenvolvimento De Recursos Humanos: Como Incrementar Talentos Na Empresa (7th ed.). São Paulo: Atlas.

Costa, M. A. F., \& Costa, M. F. B. (2001). Metodologia da Pesquisa-Conceitos. Inter Ciência.

Dana, L. P., \& Dana, T. E. (2005). Expanding the scope of methodologies used in entrepreneurship research. International Journal Entrepreneurship and Small Business, 2(1), 79-88. https://doi.org/10.1504/IJESB.2005.006071

Dana, L. P., \& Dumez, H. (2015). Qualitative research revisited: epistemology of a comprehensive approach. International Journal of Entrepreneurship and Small Business, 26(2), 154-170. https://doi.org/10.1504/IJESB.2015.071822 
Degen, R. J. (1989). O Empreendedor: fundamentos da iniciativa empresarial. São Paulo: Mcgraw-Hill.

Dencker, A. F. M. (1998). Métodos E Técnicas De Pesquisa Em Turismo (3rd ed.). São Paulo: Futura.

Dornelas, J. C. A. (2015). Empreendedorismo na prática: mitos e verdades do empreendedor de sucesso. Rio de Janeiro: Elsevier.

Filion, L. J. (1999). Empreendedorismo: empreendedores e proprietários-gerentes de pequenos negócios. Revista de Administração, 34(2), 5-28.

Gil, A. C. (2002). Como Elaborar Projetos de Pesquisa. São Paulo.

Hisrich, R. D., \& Peters, M. P. (2002). Entrepreneurship (5th ed.).

JUCESP. (2018). Junta Comercial do Estado de São Paulo. Serviços online. Retrieved June 8, 2018, from https://www.jucesponline.sp.gov.br/mapas.aspx

Knight, F. (1921). Risk, Uncertainty and Profit. Houghton Mifflin, Boston.

Kuratko, D. F. (2009). The entrepreneurial imperative of the 21st century. Business Horizons, 52(5), 421-428. https://doi.org/10.1016/j.bushor.2009.04.006

Kuratko, D. F. (2011). Entrepreneurship theory, process, and practice in the 21st century. International Journal of Entrepreneurship and Small Business, 13(1), 8-17. https://doi.org/10.1504/IJESB.2011.040412

Leitão, J., Lasch, F., \& Thurik, R. (2011). Globalisation, entrepreneurship and regional environment. International Journal Entrepreneurship and Small Business, 12(2), 129-138. https://doi.org/10.1504/IJESB.2011.038562

Mesquita, J. M. C., Martins, H. C., Dias, A. T., \& Rabelo, A. (2016). Impactos Da Sazonalidade Da Produção Sobre Os Estoques E Lucratividade: Análise Do Segmento Industrial Brasileiro. Contabilidade Vista \& Revista, 27(3), 61-80.

Miner, J. B. (1996). Evidence for the existence of a set of personality types, defined by psychological tests, that predict entrepreneurial success. Frontiers of Entrepreneur Research, Edition, Babson College.

Mota, K. C. N. (2001). Marketing Turístico: Promovendo Uma Atividade Sazonal. São Paulo: Atlas.

Nacional, S. (2016). Conheça Características Importantes Para O Comportamento Empreendedor. Retrieved from Http://Www.Sebrae.Com.Br/Sites/Portalsebrae/Artigos/Conhecacaracteristicas-Importantes-Para-OComportame ntoempreendedor,638b5d27e8fdd410vgnvem1000003b74010arcrd

Nissan, E., Galindo, M. E., \& Mendez, M. (2011). Relação entre organizações, instituições, empreendedorismo e processo de crescimento econômico. Jornal Internacional Empreendedorismo e Gestão, 7(3), 311-324.

Porto, R. B., Santos, P. M. F., \& Santana, F. V. (2017). Desempenho Na Rede Social E Receita Em Vendas: Efeito Moderador Da Sazonalidade Na Pequena Empresa Varejista. Remark-Revista Brasileira De Marketing, 16(1), 115-129. https://doi.org/10.5585/remark.v16i1.3297

Rembeza, J., Przekota, G., Klonowska-Matynia, M., \& Radlińska, K. (2016). Seasonal changes in the matching function: case study for Poland, Country experiences in economic development, management and entrepreneurship. Eurasian Studies in Business and Economics, 5. https://doi.org/10.1007/978-3-319-46319-3_23

Ribeiro, S. D., \& Huarng, K.-H. (2013). Innovation and entrepreneurship in knowledge industries. Journal of Business Research, 66(10). https://doi.org/10.1016/j.jbusres.2013.02.019

Rocha, F. A. F., Teixeira, J. C. M., Calazans, D. L. M. E. S., Rocha, A. V., \& Madruga, M. B. (2017). As Contribuições Da Internet Nos Efeitos Da Sazonalidade: Um Estudo Realizado Em Um Hotel De Pequeno Porte. Brazilian Jornal of Management \& Innovation, 4, 42-63. https://doi.org/10.18226/23190639.v4n2.03

Sampaio, R. (2006). Ocupação das orlas das praias paranaenses pelo uso balneário. In Desenvolvimento E Meio Ambiente (pp. 169-186). Curitiba: Editora Da Ufpr. https://doi.org/10.5380/dma.v13i0.9850

Scheuer, L., \& Miguel, B. A. H. L. (2011). Sazonalidade do turismo no município de Guaratuba, Paraná, Brasil. Raega-O Espaço Geográfico em Análise, 23. https://doi.org/10.5380/raega.v23i0.24841

Schumpeter, J. (1931). Theorie der wirtschaftlichen Entwichlung, Dunker und Humblat, Munich and Leipzig.

Shane, S., \& Venkataraman, S. (2000). The promise of entrepreneurship as a field of research, Academy of Management. The Academy of Management Review. https://doi.org/10.2307/259271 
Supriatna, A., Hertini, E., Susanti, D., \& Supian, S. (2017). Prediction of tourist arrivals to the Island of Bali. The Faculty of Mathematics and Natural Sciences, Yogyakarta State University, 6(2).

Vesper, K. H. (1980). Perspectives on entrepreneurship. In New Venture Strategies (pp. 1-26). Englewood Cliffs: Prentice Hall.

Welter, F., \& Smallbone, D. (2011). Conceptualising entrepreneurship in a transition context. International Journal of Entrepreneurship and Small Business, 3(2), 165-184. https://doi.org/10.1504/IJESB.2006.008928

Zikmund, W. G. (2000). Business Research Methods (6th ed.). The Dryden Press.

\section{Appendix}

\section{Annex: Script of interviews}

1. a) Company name b) Address.

2. a) Trade in goods or provision of services? b) Main Product or Service?

3. Size (Individual Micro Entrepreneur / Microenterprise or Informal?)

4. When does your high sales season occur?

5. Number of employees at high and low.

6. Name, telephone and email of the interviewee.

7. Type: Natural, Learn, Serial, Corporate, Social, Need, Heir or Planned.

8. Cost calculation: Do not calculate, By yourself, Calculator, Computer, Accountant, Other.

9. Do you decide based on this calculation?

10. Does the information generated by your accountant help you manage the business?

\section{Copyrights}

Copyright for this article is retained by the author(s), with first publication rights granted to the journal.

This is an open-access article distributed under the terms and conditions of the Creative Commons Attribution license (http://creativecommons.org/licenses/by/4.0/). 